\title{
The influence of the Jigsaw learning model on mutual respect attitudes for grade VIII Junior High School students
}

\author{
Lucky Nadya ${ }^{1}$, Ridwan Santoso ${ }^{2}$ \\ ${ }^{1}$ SMP Qur'an Darul Ikhlas, Pringsewu, Indonesia \\ ${ }^{2}$ MKU STIKes Widya Dharma Husada, Tangerang Selatan, Indonesia
}

\begin{abstract}
This study aims to determine the effect of the use of Jigsaw learning model on mutual respect in grade VIII junior high school students. The study population consisted of 3 classes totaling 72 students. The sample of this research is class VIII students, amounting to 23 students. The determination of the sample class of this study was carried out using random sampling techniques. The research data were obtained through the distribution of pre-test and post-test in which validity were tested using the product moment formula. Research data were analyzed using quantitative techniques through independent sample t-test. The results showed that the use of the Jigsaw learning model had a significant effect on the mutual respect of students in the eighth grade. The results of this study can be a reference for education practitioners and related parties to instill mutual respect for students in schools, especially in the learning process. These findings can be further research material to find models, methods, or media that can be used by education practitioners and related parties for character education in schools.
\end{abstract}

\section{Article History: \\ Submitted : :29-12-2019 \\ Revised : :16-03-2021 \\ Accepted : :26-03-2021}

Keywords:

learning; model; Jigsaw; attitudes; respect

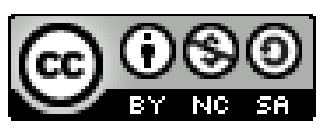

Cite in APA ${ }^{\text {th }}$ :

Nadya, L., \& Santoso, R. (2021). The influence of the Jigsaw learning model on mutual respect attitudes for grade VIII junior high school students. Jurnal Civics: Media Kajian Kewarganegaraan, 18(1), 109-117. doi:https://doi.org/10.21831/jc.v18i1.29130

\section{Introduction}

Education is part of the development process that cannot be eliminated in human life. Education obtained from the family, school, and community environment is a very influential factor in individual development. Through the educational process an individual can develop his / her potential. According to Sudjana (2008) learning is a process in an individual with a sign of a change in the individual. As the definition of education according to the National Education System Law No. 20 of 2003, that education is a conscious, planned effort to create an atmosphere of learning and the learning process so that students actively develop their potential to have religious spiritual strength, self-control, personality, noble character, and skills needed by themselves, society, the nation, and country.

Learning in schools is a learning interaction conducted by educators on students in teaching and learning activities. Sardiman (2007, p. 100), states that "learning activities are an important process in teaching and learning interactions in schools". This is because each learning component is digital or non-digital such as learning materials, learning models, learning methods, learning media, and assessment or evaluation of learning that has a significant influence and role in helping teachers achieve the success of the learning process of students (Andersson \& Palm, 2017; Panigrahi et al., 2018; Rosyid et al., 2018; Vong \& Kaewurai, 2017; Zendler \& Greiner, 2020; Zwart 
Lucky Nadya, Ridwan Santoso. The influence of the Jigsaw learning model on mutual respect attitudes for grade VIII Junior High School students

et al., 2020). Therefore, teachers need learning components that are appropriate and mutually supportive to achieve the desired learning outcomes.

Learning objectives are the main points that play a very important role in the direction of the implementation of learning. The implementation of the 2013 curriculum gave many changes to the process of implementing education in Indonesia. The teacher no longer functions as the main learning resource, but as a facilitator for the implementation of the learning process in the classroom. This is because the 2013 curriculum learning places students at the center of the learning process. It aims to provide students with a more learning experience in cognitive, affective, and psychomotor aspects. Therefore, teachers must be able to become good learning facilitators, because the creation of an effective learning process is strongly influenced by teacher professionalism, teacher teaching skills, and the created classroom learning climate (Tavakoli \& Baniasad-Azad, 2017).

Cooperative learning is a form of learning that can be used to create student-centered learning (Jacobs \& Renandya, 2019). This is in accordance with the results of research by Azizan et al., (2018), Azmin (2015), and Tran (2019) which prove that the cooperative learning process is effective in improving teamwork abilities or student performance and producing knowledgeable students. Even through the cooperative learning process it can reduce the use of alcohol by students as a result of increased social interaction and social relations between peers from the cooperative learning process (Van Ryzin \& Roseth, 2019a).

The implementation of the 2013 curriculum requires students to develop three aspects of learning in the realm of knowledge, attitudes, and skills in a balanced manner. Students are no longer required to only be able to develop intellectual knowledge, but must be able to have skills that are in accordance with their talents and interests and have the noble character of the Indonesian people. In the realm of attitudes, it can be identified from the release of the 18 character education values program for students that must be internalized to each student namely religious character, honesty, tolerance, discipline, independence, love of the motherland, hard work, creative, curiosity, democracy, national spirit, respect for achievement, communicative, peace-loving, social care, fond of reading, responsibility, and cares for the environment. These values must be instilled in students. Therefore, teachers need to choose and innovate models and media that will be used in the learning process to maximize the 18 character education value program based on (Presidential Regulation No. 87: 2017).

Creating a character learning process for students is one of the roles that teachers can give to shape the character of the nation. Every subject teacher has a big share in implementing character education in schools. However, Pancasila and civic education teachers are the teachers who have the greatest share in instilling an attitude of mutual tolerance or mutual respect in student because the values of tolerance and mutual respect are very important values in the implementation of Pancasila in the social life of society.

Recognition of equality, rights, and obligations of fellow human beings, loving each other, tolerating, not being arbitrary towards others, upholding human values, daring to defend truth and justice, and respect for every difference in Indonesian society which is very various are just a few of the many types of implementation of the values contained in Pancasila.

The use of the right learning model will greatly help teachers in instilling character values in students. Such as a learning model which requires question and answer and discussion activities indirectly teach students to learn to be open to respect the opinions of others (Craig \& Yousuf, 2018), because the character that is internalized into the behavior of a student is not formed automatically but through the teaching process (Nucci et al., 2014). The teacher needs to arrange 
an appropriate learning process to instill character in students one of ways is by using a learning model that is in accordance with the objectives of the learning outcomes to be achieved. One of the learning models which learning syntax has been widely known is the Jigsaw cooperative learning model. The Jigsaw cooperative learning model is a model that requires discussion between groups. So, it is expected that through the use of the Jigsaw cooperative learning model, it can instill a character of tolerance in students specifically about mutual respect.

The form of mutual respect from students in the learning process can be seen from the creation of cooperation among students or between students and teachers in the learning process. One form of mutual respect for students in the learning process using the Jigsaw cooperative learning model is listening well and not interrupting when other group members give explaination. Likewise, when the teacher is explaining material or other information, students are expected to listen well and ask or argue if they are welcome. The results of the research by Van Ryzin and Roseth (2019b) and Van Ryzin et al., (2020) prove that cooperative learning has an effect on increasing prosocial attitudes and peer relations to empathize with each other between individuals which has the impact of supporting antibullying attitudes. That is because there are many negative impacts that arise from the character of tolerance or mutual respect in a human being.

The results of these studies are the basis for the importance of research results which prove that there is an effective learning model to improve the character of mutual tolerance of students in the classroom. The goal is for teachers to use appropriate learning models in the learning process in realizing characterful learning for students. Santrock (2013) states that character education is an effort that can be made by teachers in preventing the possibility of characterless (preventive) actions in an individual that might endanger others or themselves. Therefore, it is important to have accurate information about an effective, and efficient learning model to instill mutual respect in students in the learning process at school.

\section{Method}

This research is a quantitative research with a quasi-experimental research type with a one group pre-test and post-test design. This type of quasi-experimental research was chosen to determine the causes and effects that might occur between the independent variable and the dependent variable. The independent variable in this study is the Jigsaw cooperative learning model $(X)$ and the dependent variable in this study is mutual respect $(\mathrm{Y})$.

The population of this study was 72 students at the Qur'an Darul Ikhlas Pringsewu school year 2019/2020. The sample of this research was class VIII, amounting to 23 students. The sampling technique used was random sampling by considering the weight of the learning load, the mutual respect shown, and input from the teachers of SMP Qur'an Darul Ikhlas Pringsewu because of the problem of attitudes in grade VIII students.

The research data were obtained by using the distribution of pre-test and post-test to 23 respondents. The use of a questionnaire instrument in this study is due to measuring mutual respect in students. The distribution of pre-test and post-test was given before learning using the Jigsaw cooperative learning model (pre-test) and after using the Jigsaw cooperative learning model (post-test). Instruments (pre-test) and (post-test) are two different instruments but have an equal level to measure the effect of using the Jigsaw-type cooperative learning model on students' mutual respect.

The validity of the research instrument was obtained by using the product moment correlation formula with the help of the SPSS 24 program. The reliability of the instrument was obtained using the Alpha Cronbach's formula with the help of the SPSS 24 program. Parametric 
Lucky Nadya, Ridwan Santoso. The influence of the Jigsaw learning model on mutual respect attitudes for grade VIII Junior High School students

statistics with the help of the SPSS 24 program. Data analysis techniques and research hypothesis testing were carried out using the independent sample t-test with the help of the SPSS 24 program.

\section{Results and Discussion}

The results of observations at SMP Qur'an Darul Ikhlas Pringsewu found that there were problems with lack of or low mutual respect for students. Lack of mutual respect for students is seen when the teacher is explaining material or information, many students interrupt the teacher's explanation with questions or jokes. Likewise, when the process of conveying opinions from fellow students, other students often argue before their friends finish explaining the material, questions, answers, or other information.

Character education is part of the affective aspect domain in the education process in schools. Character education carried out in Indonesia aims to instill Pancasila values in the form of characters according to the norms applied in the social life of Indonesian society. Pala's research results (2011) show character education is one of the factors that greatly affects the success of the academic education process of a student at school. Arthur (2003) stated that the task of a teacher is to provide appropriate provisions for students in the aspects of knowledge, attitudes, and skills in accordance with the norms and ethics that apply in social life, including Indonesia.

Learning using the Jigsaw type of cooperative learning model is effective learning if it is used to train cohesiveness, friendly, communicative, and tolerant character because, cooperative learning is a form of learning that prioritizes cooperation between students in a group (Muslimin \& Nur, 2000). As the results of the research by Indriwati et al., (2019) that the use of the Jigsaw type of cooperative learning model can improve student cooperation.

The research data showed an increase in mutual respect for students. This can be seen from the data from the pre-test and post-test results to the research respondents. The increase in posttest results on research respondents did not only occur with the increase in the number of highvalue frequencies on the post-test result but it also happened, there was an increase in the lowest score or the smallest value when the post-test was carried out on students after the learning process using the Jigsaw cooperative learning model.

Increasing mutual respect for students is evidence of the suitability of the Jigsaw type of cooperative learning model to be used in learning that aims to instill mutual respect. The purpose of implementing the pre-test is to see the level of mutual respect for students before using the Jigsaw type of cooperative learning model. Meanwhile, the purpose of implementing the post-test is to see the learning outcomes using the Jigsaw-type cooperative learning model for mutual respect for students. The following are the data from the pre-test and post-test results of students.

Picture Data Pre-Test and Postest
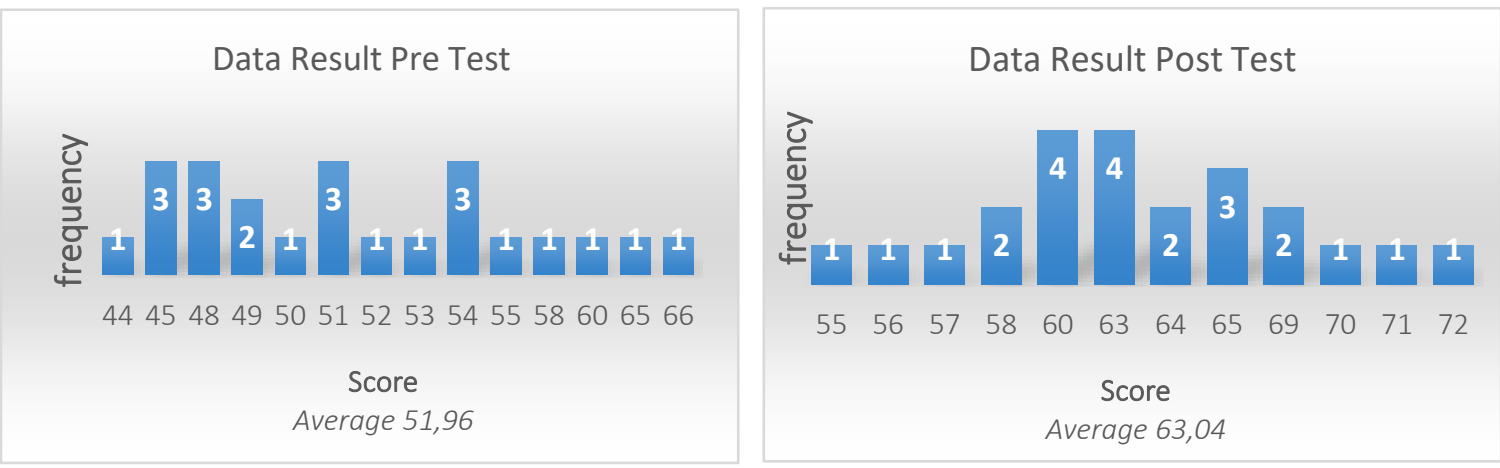
Based on the pre-test and post-test diagrams, it is known that the lowest pre-test score is 44 and the highest score is 65 and has an average score of 51.96. The data improved in the posttest results with the lowest score being 55 and the highest score being 72 and having an average score of 63.04. The increase that occurs in the pre-test and post-test diagram data shows an increase in the mutual respect of students in facing a condition that requires decision-making actions to be more respectful and restrained. The use of pre-test and post-test instruments is based on the results of validity testing using the Pearson Bivariate Correlations (Product Moment) formula which proves that each pre-test and post-test item obtains a t-count score greater than $\mathrm{t}$-table at a significance level of $5 \%$ which proves that the research instrument is valid to use. These results are in line with the results of the instrument reliability test which shows the Cronbach's Alpha score of 0.913 is greater than 0.90 which proves that the instrument is reliable.

Table 1.

\begin{tabular}{cc}
$\frac{\text { Cronbach's Alpha Test Results }}{\text { Reliability Statistics }}$ \\
\hline $\begin{array}{c}\text { Cronbach's Alpha } \\
\text {.913 }\end{array}$ \\
\hline Source: primary research data
\end{tabular}

The data on the increase in the pre-test and post-test diagrams of using the Jigsaw type of cooperative learning model for mutual respect for students was carried out by a prerequisite analysis before testing the hypothesis. The results of the normality test using the Shapiro Wilk formula with the help of the SPSS 24 program on the pre-test result data obtained a score of 0.349 . While the results of the normality test on the post-test result data obtained a score of 0.516. Based on the normality test score, it can be seen that all research data have a significance value of more than 0.05, which means that all data from the pre-test and post-test results are normally distributed.

The homogeneity test of the research data was obtained by using the levene statistical formula with the help of the SPSS 24 program obtain a score of 0.476 . These results prove that the homogeneity test score of 0.476 is greater than 0.05 , which means that the research data are homogeneous. Based on the results of the prerequisite test for normality and homogeneity of research data, the research data fulfill the requirements for analysis or hypothesis testing using parametric statistical tests.

Hypothesis testing in this study used statistical independent sample t test with the help of the SPSS 24 program. The testing criteria were Ha was accepted and Ho was rejected if the significance value was $<0.05$ and $\mathrm{Ha}$ was rejected and $\mathrm{Ho}$ was accepted if the significance value was $>0.05$. Based on the results of the independent sample $t$ test, it shows that the significance value of the research data is $0.000<0.05$, which means that $\mathrm{Ha}$ is accepted and $\mathrm{Ho}$ is rejected. These results mean that there is a significant effect of the use of the Jigsaw cooperative learning model on mutual respect for grade VIII students of SMP Qur'an Darul Ikhlas Pringsewu.

Table 2.

The results of the independent sample t test

\begin{tabular}{ccc}
\hline $\mathrm{t}$ & $\mathrm{df}$ & sig. (2-tailed) \\
\hline$-6,598$ & 28 & 0,000 \\
\hline
\end{tabular}

Source: primary research data

The results of the research hypothesis test form the basis that the Jigsaw cooperative learning model is the right model to be used in instilling mutual respect. The Jigsaw type of cooperative learning model is a learning model that divides students into small groups that will 
Lucky Nadya, Ridwan Santoso. The influence of the Jigsaw learning model on mutual respect attitudes for grade VIII Junior High School students

function as "home groups" and "expert groups" (Mulyatiningsih, 2014). With the division of tasks as an expert group and a home group, psychologically, students will have the opportunity to practice communicating in front of the group, discussing groups, and asking questions. In the discussion phase between the expert group and the home group, the mutual respect character education is formed by students.

Cooperative learning has a positive impact on a student's attitude in learning (Gerald \& Allan, 2018). In fact, based on the results of research by Mengduo (2010), the use of the Jigsaw type of cooperative learning model is an effective way of increasing student participation and increasing student achievement. The participation of students in this case can occur when students exchange opinions between groups which can increase the competence of students to ask other groups. The results of research by Ghaith and Bouzeineddine (2003), Sharan (1980), Rabgay (2018), and Brown and Mezieobi (2017) prove that the learning process using Jigsaw provides a more learning experience for learning achievement and the development of students' attitudes.

The Jigsaw type of cooperative learning model can also have an impact on the desire of students to learn. As the results of research by Rachmah (2017), Indriwati et al., (2019), and Sanaie et al., (2019) stated that the Jigsaw cooperative learning model has a positive effect on students' learning motivation. Even based on the research results of Sabbah (2016) and Khairunisa et al., (2019), the Jigsaw cooperative learning model affects students' reading ability. This is because students who get the task of being an expert group are tasked with explaining the material to the original group so that indirectly the expert group makes more reading material to explore the material before explaining to the original group.

The type of Jigsaw cooperative learning model can also affect students' confidence in their abilities. The research results of Juliana and Surya (2017) show that the use of the Jigsaw-type cooperative learning model affects students' self-confidence. In addition, the research results of Indriwati et al., (2019) show that the Jigsaw cooperative learning model can increase students' self-efficacy. This self-efficacy is related to the belief that the self has the ability to take the expected action. Besides having a positive impact on the affective aspects of students, the use of the Jigsaw type of cooperative learning model also has an influence on the cognitive aspects of students. The results show that the use of the Jigsaw cooperative learning model affects learning outcomes and student achievement (Jazuli \& Ahmad, 2009; Kautsar et al., 2018).

The type of Jigsaw cooperative learning model can also affect students' critical thinking skills. It is In line with the results of research conducted by Saputra et al., (2019), which showed that students' critical thinking skills increased significantly after the Jigsaw type cooperative learning model was applied, especially when combined with a problem-based learning model. By applying the Jigsaw type of cooperative learning model, it will train students to be brave in expressing opinions, working together, developing themselves, and being individually responsible, positive interdependence, personal interaction and group processes. The use of this learning model effectively and efficiently will make the learning process centered on students and the teacher will only function as a supervisor or facilitator.

The learning process that exchanges information between groups of students through discussion, question and answer, and responding is a form of habituation to respect the opinions of others. Therefore, the results of the research conducted show a significant effect of the use of the Jigsaw-type cooperative pursuit model on mutual respect between students or students and the teacher. The results of this study can be a reference material for teachers and other education practitioners in implementing character education in schools using the Jigsaw-type cooperative learning model which is proven to be effective in increasing the character of mutual respect in students. 


\section{Conclusions}

The Jigsaw type of cooperative learning model is a learning model that has a positive impact on the three domains of education (affective, cognitive, and psychomotor). The type of Jigsaw cooperative learning model has a positive impact on learning outcomes, learning achievement, mutual respect, a sense of responsibility, and students' communicative skills. Evidenced by the results of the study, the post-test average score was higher than the pre-test average, which was 64.20> 52.67. Likewise, hypothesis testing shows that the significance value is $0.000<0.05$, which means that $\mathrm{Ha}$ is accepted and $\mathrm{Ho}$ is rejected, meaning that there is a significant effect of the Jigsaw cooperative learning model on the mutual respect of class VIII students. These findings are expected to provide the right choice for a teacher to carry out character education, especially the cultivation of mutual respect. The results of this study can be the basis for further research to find models or other learning methods that are appropriate and effective for the implementation of character education in schools.

\section{References}

Andersson, C., \& Palm, T. (2017). The impact of formative assessment on student achievement: A study of the effects of changes to classroom practice after a comprehensive professional development programme. Learning and Instruction, 49(June), 92-102. https://doi.org/10.1016/j.learninstruc.2016.12.006

Arthur, J. (2003). Education with character. The moral economy of schooling. RoutledgeFalmer. https://doi.org/10.4324/9780203220139

Azizan, M. T., Mellon, N., Ramli, R. M., \& Yusup, S. (2018). Improving teamwork skills and enhancing deep learning via development of board game using cooperative learning method in Reaction Engineering course. Education for Chemical Engineers, 22(January), 1-13. https://doi.org/10.1016/j.ece.2017.10.002

Azmin, N. H. (2015). Effect of the jigsaw-based cooperative learning method on student performance in the general certificate of education advanced-level psychology: An exploratory brunei case study. International Education Studies, 9(1), 91. https://doi.org/10.5539/ies.v9n1p91

Brown, T., \& Mezieobi, S. (2017). Cooperative learning method and junior secondary students'attitude towards citizenship education in social studies in rivers state, Nigeria. British Journal of Education, 5(4), 1-8.

Craig, D. A., \& Yousuf, M. (2018). Teaching and assessing learning about virtue: insights and challenges from a redesigned journalism ethics class. Journal of Media Ethics: Exploring Questions of Media Morality, 33(4), 181-197. https://doi.org/10.1080/23736992.2018.1509714

Gerald, B., \& Allan, M. (2018). Effect of cooperative learning on students' attitude and performance towards probability distributions in statistics. Journal of Education and Practice, 9(14), 43-50.

Ghaith, G. M., \& Bouzeineddine, A. R. (2003). Relationship between reading attitudes, achievement, and learners' perceptions of their jigsaw ii cooperative learning experience. Reading Psychology, 24(2), 105-121. https://doi.org/10.1080/02702710390197444 
Lucky Nadya, Ridwan Santoso. The influence of the Jigsaw learning model on mutual respect attitudes for grade VIII Junior High School students

Indriwati, S. E., Susilo, H., \& Hermawan, I. M. S. (2019). Improving students' motivation and collaborative skills through Remap Jigsaw learning combined with modelling activities. Jurnal Pendidikan Biologi Indonesia, 5(2), 177-184. https://doi.org/10.22219/jpbi.v5i2.7888

Jacobs, G. M., \& Renandya, W. A. (2019). Student centered cooperative learning: An introduction. In Student Centered Cooperative Learning (pp. 1-17). Springer, Singapore. https://doi.org/10.1007/978-981-13-7213-1_1

Jazuli, A., \& Ahmad. (2009). Jigsaw type of cooperative learning as a means of improving high school-students' mathematical communication ability. EDUCARE: International Journal for Educational Studies, 1(2). https://doi.org/10.2121/EDU-IJES.V1I2.203

Juliana, M., \& Surya, E. (2017). An analysis of jigsaw cooperative efectiveness to improve the selfconfidence and learning result of vacational high school students. IJARIIE, 3(2), 3520-3526.

Kautsar, A., Marzuki, M., \& Sadrina, S. (2018). Pengaruh penerapan model pembelajaran kooperatif tipe jigsaw terhadap hasil belajar siswa pada mata pelajaran teknik instalasi penerangan listrik rumah sederhana di SMKN 1 Darul Kamal. CIRCUIT: Jurnal IImiah Pendidikan Teknik Elektro, 2(2), 90-101. https://doi.org/10.22373/crc.v2i2.3699

Khairunisa, A., Rosnija, E., \& Rezeki, Y. S. (2019). Improving students' reading comprehension on romance narrative text by using jigsaw. Jurnal Pendidikan Dan Pembelajaran Khatulistiwa, 8(3), 1-9. https://jurnal.untan.ac.id/index.php/jpdpb/article/view/32299

Mengduo, Q. (2010). Jigsaw strategy as a cooperative learning technique: Focusing on the language learners. Chinese Journal of Applied Linguistics (Foreign Language Teaching \& Research Press), 33(4).

Mulyatiningsih, E. (2014). Metode penelitian terapan bidang pendidikan. Alfabeta.

Muslimin, I., \& Nur, M. (2000). Pembelajaran kooperatif. University Press.

Nucci, L., Krettenauer, T., \& Narvaez, D. (Eds.). (2014). Handbook of moral and character education (2nd ed.). Routledge.

Panigrahi, R., Srivastava, P. R., \& Sharma, D. (2018). Online learning: Adoption, continuance, and learning outcome-A review of literature. In International Journal of Information Management (Vol. 43, pp. 1-14). Elsevier Ltd. https://doi.org/10.1016/j.ijinfomgt.2018.05.005

Pala, A. (2011). The need for character education. International Journal of Social Sciences And Humanity Studies, 3(2), 23-32. https://dergipark.org.tr/en/pub/ijsshs/276136

Rabgay, T. (2018). The effect of using cooperative learning method on tenth grade students' learning achievement and attitude towards biology. International Journal of Instruction, 11(2), 265-280. https://doi.org/10.12973/iji.2018.11218a

Rachmah, D. N. (2017). Effects of jigsaw learning method on students' self-efficacy and motivation to learn. Journal of Educational, Health and Community Psychology, 6(3), 1. https://doi.org/10.12928/jehcp.v6i3.8314

Rosyid, H. A., Palmerlee, M., \& Chen, K. (2018). Deploying learning materials to game content for serious education game development: A case study. Entertainment Computing, 26(May), 19. https://doi.org/10.1016/j.entcom.2018.01.001

Sabbah. (2016). The effect of jigsaw strategy on ESL students' reading achievement. Arab World English Journal, 7(1), 445-458. https://doi.org/10.24093/awej/vol7no1.27 
Sanaie, N., Vasli, P., Sedighi, L., \& Sadeghi, B. (2019). Comparing the effect of lecture and Jigsaw teaching strategies on the nursing students' self-regulated learning and academic motivation: A quasi-experimental study. Nurse Education Today, 79(August), 35-40. https://doi.org/10.1016/j.nedt.2019.05.022

Santrock, J. (2013). Adolescence (15th ed.). McGraw-Hill.

Saputra, M. D. (2019). Developing critical-thinking skills through the collaboration of jigsaw model with problem-based learning model. International Journal of Instruction, 12(1), 1077-1094. https://doi.org/10.29333/iji.2019.12169a

Sardiman. (2007). Interaksi dan motivasi belajar mengajar. PT Grafindo.

Sharan, S. (1980). Cooperative learning in small groups: Recent methods and effects on achievement, attitudes, and ethnic relations. Review of Educational Research, 50(2), 241271. https://doi.org/10.2307/1170146

Sudjana, N. (2008). Penilaian hasil proses belajar mengajar. Remaja Rosdakarya.

Tavakoli, M., \& Baniasad-Azad, S. (2017). Teachers' conceptions of effective teaching and their teaching practices: a mixed-method approach. Teachers and Teaching: Theory and Practice, 23(6), 674-688. https://doi.org/10.1080/13540602.2016.1218326

Tran, V. D. (2019). Does cooperative learning increase students' motivation in learning? International Journal of Higher Education, 8(5), 12-20. https://doi.org/10.5430/ijhe.v8n5p12

Van Ryzin, M. J., \& Roseth, C. J. (2019a). Cooperative learning effects on peer relations and alcohol use in middle school. Journal of Applied Developmental Psychology, 64(July-Septermber), 101059. https://doi.org/10.1016/j.appdev.2019.101059

Van Ryzin, M. J., \& Roseth, C. J. (2019b). Effects of cooperative learning on peer relations, empathy, and bullying in middle school. Aggressive Behavior, 45(6), 643-651. https://doi.org/10.1002/ab.21858

Van Ryzin, M. J., Roseth, C. J., \& Biglan, A. (2020). Mediators of Effects of Cooperative Learning on Prosocial Behavior in Middle School. International Journal of Applied Positive Psychology, 5(1-2), 37-52. https://doi.org/10.1007/s41042-020-00026-8

Vong, S. A., \& Kaewurai, W. (2017). Instructional model development to enhance critical thinking and critical thinking teaching ability of trainee students at regional teaching training center in Takeo province, Cambodia. Kasetsart Journal of Social Sciences, 38(1), 88-95. https://doi.org/10.1016/j.kjss.2016.05.002

Zendler, A., \& Greiner, H. (2020). The effect of two instructional methods on learning outcome in chemistry education: The experiment method and computer simulation. Education for Chemical Engineers, 30(January), 9-19. https://doi.org/10.1016/j.ece.2019.09.001

Zwart, D. P., Noroozi, O., Van Luit, J. E. H., Goei, S. L., \& Nieuwenhuis, A. (2020). Effects of Digital Learning Materials on nursing students' mathematics learning, self-efficacy, and task value in vocational education. Nurse Education in Practice, 44(March), 102755. https://doi.org/10.1016/j.nepr.2020.102755 